\title{
Screening, counseling and referral pattern of structural heart disease in pregnancy cases at public health center in Surabaya
}

\author{
Noorma Rina Hanifah', Andrianto², Bambang Trijanto' \\ 'Department of Obstetric and Gynecology, ${ }^{2}$ Department of Cardiology and Vascular Medicine, Faculty of Medicine, \\ Universitas Airlangga, Dr. Soetomo Hospital, Surabaya.
}

\section{ABSTRAK}

Tujuan: Mengetahui gambaran proses penapisan, konseling dan pola rujukan penyakit jantung struktural dalam kehamilan oleh PHC di Surabaya sebagai data awal yang dibutuhkan untuk penyusunan standar perawatan kehamilan dengan penyakit jantung.

Bahan dan Metode: Penelitian kualititatif dengan metode wawancara mendalam pada dokter PJ KIA PHC yang dipilih dengan cara purposive sampling, keterangan tersebut dikonfirmasi dengan keterangan Kepala Unit Manajemen Pelayanan Primer BPJS cabang Surabaya, staf Unit Kesehatan Keluarga Dinas Kesehatan Kotamadya Surabaya dan 8 pasien hamil dengan penyakit jantung struktural yang dirawat di RSUD Dr. Soetomo

Hasil: Proses pemeriksaan kehamilan awal di PHC dilakukan sesuai dengan format kartu ibu yang tidak dirancang untuk penapisan penyakit jantung struktural dalam kehamilan, anamnesis dan pemeriksaan fisik yang khusus untuk penapisan penyakit jantung baru dilakukan bila dicurigai terdapat penyakit jantung struktural dalam kehamilan. Dokter PJ KIA PHC belum sepakat mengenai tujuan rujukan untuk kasus kehamilan dengan kecurigaan penyakit jantung struktural karena belum ada panduan yang mengatur. Konseling yang dilakukan terhadap pasien hamil yang dicurigai menderita penyakit jantung struktural masih terbatas pada pemberian informasi bahwa PHC tidak mampu menegakkan diagnosis

Simpulan: Proses penapisan penyakit jantung struktural dalam kehamilan selama ini tidak rutin dilakukan selama ANC. Belum ada panduan baku mengenai proses perujukan kasus kehamilan dengan kecurigaan adanya penyakit jantung struktural yang bisa dilaksanakan oleh dokter PJ KIA PHC. Kunjungan perempuan penderita penyakit jantung struktural ke PHC untuk memperoleh surat rujukan ke fasilitas kesehatan tingkat sekunder/tersier dan program Usaha Kesehatan Sekolah belum dimanfaatkan untuk pelaksanaan konseling mengenai pengaruh penyakit jantung terhadap kesehatan reproduksi. (MOG 2017;25:103-112)

Kata kunci: Penyakit jantung struktural dalam kehamilan; penapisan; rujukan; $\mathrm{PHC}$

\section{ABSTRACT}

Objectives: To depict the process of screening, counseling and referral patterns of structural heart disease in pregnancy cases by public health centre in Surabaya as preliminary data required for the groundwork of standard of care of pregnancy with heart disease.

Materials and Methods: This is a qualitative research with indepth interview to PJ KIA doctors selected by purposive sampling, the information is confirmed by the Head of Primary Service Management Unit of BPJS Surabaya branch, Family Health Unit staff of Surabaya Municipality Health Office and 8 patients with structural heart disease in pregnancy treated in RSUD Dr. Soetomo

Results: The process of early pregnancy screening at the $\mathrm{PHC}$ is performed by midwives and GPs in accordance to the format provided by of the Surabaya Municipality Health Office which was not designed for structural heart disease screening in pregnancy, history taking and special physical examination for screening of heart disease only done if suspicion occurs. Medical and Child Health program overseer doctors have not agreed on which referral facility for pregnancy cases with suspicion of structural heart disease should be directed because there is no guiding regulation. Counseling of pregnant patients suspected of having structural heart disease is still limited to providing infor-mation that PHC are unable to make a diagnosis.

Conclusion: The process of screening for structural heart disease during pregnancy has not been done routinely through anamnesis and physical examination. There is no standard guidance on the process of referral of pregnancy cases with suspicion of structural heart disease that can be performed by Mother and Child Health programs overseer doctors. Visits of women with structural heart disease to the PHC to obtain referral letter to secondary / tertiary health facilities and School Health Program programs have not been utilized for counseling on the effect of heart disease on reproductive health. (MOG 2017;25:103-112)

Keywords: Structural heart disease in pregnancy; screening; referral; public health centre

Correspondence: Noorma Rina Hanifah. Department of Obstetric and Gynecology, Faculty of Medicine, Universitas Airlangga, Dr. Soetomo Hospital, Jalan Prof dr Moestopo 6-8, Surabaya 60286, Indonesia. E-mail: noormarinahanifah@gmail.com

\section{INTRODUCTION}

According to the Dr. Soetomo hospital's inpatient database, there were 25 cases of structural heart disease in pregnancy in 2014, with 14 patients reside in Surabaya. In 2015 this number increase to 36 cases with 20 patients reside in Surabaya and in 2016 the number of structural heart disease cases increased further to 71 , with 18 patient reside in Surabaya. In 2016, there were
12 maternal mortality cases due to structural heart disease, with the total maternal mortality of 53 cases $(22,64 \%) 3$. In an unplanned pregnancy in structural heart disease patient, the morbidity and mortality rates of both maternal and neonatal are high. The high morbidity rate could be seen from the higher need of intensive care unit and the longer hospital stay. 
The management of pregnancy with structural heart disease require special resources hence the need to early referral of these cases to competent health care facility. With the new universal health coverage system manage by Badan Penyelenggara Jaminan Sosial (BPJS), first antenatal care (ANC) should be started at primary health care followed by systematic referral, for that reason, the referral system for structural heart disease in pregnancy cases should be structurized and simplified so there would be no delay caused by uncertain referral system.

This study aim to depict the screening process, counseling and referral pattern of structural heart disease in pregnancy cases by the public health centre (PHC) as a representative of primary health care available in Surabaya as the preliminary data needed for assembling the standard procedure of the management of structural heart disease in pregnancy cases from the primary health care until tertiary referral facility.

\section{MATERIALS AND METHODS}

This study use qualitative approach because aimed to depict the factual screening, counseling and referral process of structural heart disease in pregnancy from the PHC in Surabaya. We conduct in-depth interview with semi structural questionnaire. This study conducted from June, 1st until July, 31st 2017 at 24 PHC in Surabaya, patient residency, BPJS Surabaya office branch and Surabaya Municipality Health Office. Each interview lasted around 30 minutes.

Triangulation is a data confirmation process between researcher, study method and data source4. In this study, triangulation done by verification of information obtained from informant, patients and written record which were ANC book and medical record in PHC.

Informant choose by purposive sampling method. We selected informants from: (1) inpatient with structural heart disease in pregnancy cases at Dr. Soetomo hospital or outpatient at Dr. Soetomo high risk pregnancy clinic from January 2016 until March 2017, these patient should reside in Surabaya, done at least twice ANC at public health centre in Surabaya and referred to secondary or tertiary health referral facility by the PHC, (2) Mother and Child Health Program medical doctors who oversee in PHC in Surabaya, we choose 24 certified PHC as data sources, (3) representative from Family Health Unit of Surabaya Municipality Health Office, and (4) Head of Primary Service management Unit of BPJS Surabaya Branch Office. Ethical clearance given by Ethical Comittee Airlangga Medical Faculty/DR.
Soetomo Hospital with registration number of 374/ PankeKKE/ V/2017 dated 30 Mei 2017.

\section{RESULTS AND DISCUSSION}

We conducted in-depth interview to 24 Mother and Child Health Program comissioner in PHC and 8 patient structural heart disease in pregnancy admitted to Dr. Soetomo Hospital during January 2016 - March 2017. We obtained information about screening, counseling and referral process done in PHC from the patient's experience and officer's view. The information acquired confirmed by representative from Family Health Unit of Surabaya Municipality Health Office and Head of Primary Service management Unit of BPJS Surabaya Branch Office.

From 24 standarized PHC, there is one with a midwife as overseer of Mother and Child health program, and we exclude this PHC from our study. During the interview, other than the questionnaire, we also asked if these doctors have some experience dealing with structural heart disease in pregnancy cases and whether they have received lectures or seminars on structural heart disease in pregnancy.

There were only 9 doctors who have seen pregnancy with suspicion of structural heart disease or definitive structural heart disease in pregnancy case. Those who claimed to have not met any, can not ascertain as some pregnant women who did not gave birth in the PHC facility or did not do their ANC completely at PHC will not be followed until birth. The statement of never seen any structural heart disease in pregnancy cases based on the fact that they never received any communication letter from the hospitals about a pregnant woman with structural disease in their area.

Lectures about structural heart disease in pregnancy were last given in 2013, so that many of these doctors have never received it. The Surabaya Municipality Health Office has changed this lecture mode to hospital assisted system at 2016. This hospital assisted system involves 5 hospitals in Surabaya which will assist the PHC in their refererral area with providing selected lecture chosen by the PHC or by the most case encounter in the PHC. Until the day we conducted this interveiew to the Health Bureau representative, the hospital assisted system only involved the obstetric and gynecology department, save the Hajj hospital, where the neonatology division of Pediatric department also involved. 
Table 1. Summary of suspected or proven structural heart disease cases met by PHC overseer doctors

\begin{tabular}{|c|c|c|c|}
\hline $\mathrm{PHC}$ & New case/Diagnosed & Findings at $\mathrm{PHC}$ & Management at PHC \\
\hline PHC A & Diagnosed & - & $\begin{array}{l}\text { Returned to the hospital where she was } \\
\text { diagnosed (RS RKZ) }\end{array}$ \\
\hline PHC E & New case & Dyspneu & $\begin{array}{l}\text { Returned to other PHC where she was } \\
\text { registered as BPJS user (she then referred to } \\
\text { Dr. Soetomo hospital) }\end{array}$ \\
\hline PHC F & New case & $\begin{array}{l}\text { Palpitation, murmur }(+), \quad \text { multiple } \\
\text { PVC (ECG) }\end{array}$ & $\begin{array}{l}\text { Referred to secondary health facility, not yet } \\
\text { return to the PHC }\end{array}$ \\
\hline PHC H & Diagnosed & - & Referred to Dr. Soetomo hospital \\
\hline PHC K & Diagnosed & - & Referred to Dr. Soetomo hospital \\
\hline $\mathrm{PHCO}$ & New case & Murmur (+) & $\begin{array}{l}\text { Referred to secondary health facility, not yet } \\
\text { return to the PHC }\end{array}$ \\
\hline PHC V & New case & Dyspneu, cyanotic & $\begin{array}{l}\text { Referred to Dr. Soetomo hospital, died at the } \\
\text { ER }\end{array}$ \\
\hline PHC W & Diagnosed, never do ANC & 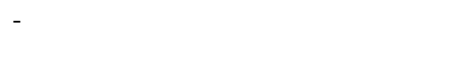 & $\begin{array}{l}\text { Referred to secondary health facility, not yet } \\
\text { return to the PHC }\end{array}$ \\
\hline PHC X & New case & Cyanotic, pale, murmur $(+)$ & $\begin{array}{l}\text { Referred to secondary health facility, not yet } \\
\text { return to the PHC }\end{array}$ \\
\hline
\end{tabular}

Lectures about structural heart disease in pregnancy were last given in 2013, so that many of these doctors have never received it. The Surabaya Municipality Health Office has changed this lecture mode to hospital assisted system at 2016. This hospital assisted system involves 5 hospitals in Surabaya which will assist the PHC in their refererral area with providing selected lecture chosen by the PHC or by the most case encounter in the PHC. Until the day we conducted this interveiew to the Health Bureau representative, the hospital assisted system only involved the obstetric and gynecology department, save the Hajj hospital, where the neonatology division of Pediatric department also involved.

\section{The screening process of structural heart disease in pregnancy at the Public Health Centre}

The pregnant patient coming for the first ANC at the PHC will first went through preliminary anamnesis by the midwife at the Mother and Child quarter, before sent to general practitioner (GP) doctor to further anamnesis and physical examination, to the dentist and to the laboratory. After all the result came out, the patient will be consulted to the GP and if needed to the nutrition consultant.

At some PHC, this first ANC (K1) patients could only be consulted to the Mother and Child Healt Program overseer GP, while in at other PHC, every GP in place would be sufficient. At the PHC where only Mother and Child Health Program Overseer could be consulted, whenever the overseer GP is not available,the K1 patient will told to come again at the time the overseer GP available, except there is emergency situation.
Table 2. Who can answer new pregnant patient consultation and the reasoning

\begin{tabular}{ll}
\hline GP/the overseer doctor & \multicolumn{1}{c}{ Reasoning } \\
\hline Overseer doctor & The lack of knowledge of other GP \\
GP & Every GP have the same competency \\
\hline
\end{tabular}

\section{Anamnesis}

We found 3 different pattern of anamnesis done by the overseer GP to the K1 patients (table 3). Another difference found was between anamnesis to the K1 pregnancy with assumed low risk and with suspicion of heart disease, based from referral note/medical history/ clinical sign. To low risk pregnancy patients, the overseer GP will not probe the possibility of heart disease further if the patient have no complain of dyspneu or breathlessness.

Table 3. Type of anamnesis done by the overseer doctor and the reasoning

\begin{tabular}{ll}
\hline \multicolumn{1}{c}{ Anamnesis } & \multicolumn{1}{c}{ Reasoning } \\
\hline Repeat all the anamnesis question & $\begin{array}{l}\text { The midwife might } \\
\text { forget and not ask some } \\
\text { of the anamnesis } \\
\text { The midwife is capable } \\
\text { to do obstetric } \\
\text { Repeat some question but not the } \\
\text { obstetric part }\end{array}$ \\
$\begin{array}{ll}\text { Do not repeat anamnesis, unless the } \\
\text { midwife report abnormality or there } \\
\text { are abnormalities found in the }\end{array}$ & $\begin{array}{l}\text { The midwife is reliable } \\
\text { and there is formal } \\
\text { physical examination }\end{array}$ \\
\hline
\end{tabular}

While in anamnesis done to the patient with suspicion of heart disease, the overseer doctors will ask more 
questions about other cardiac symptoms, even if patient denied any complain of breathlessness. The questions will be asked by the overseer doctors if the patient suspected to have heart disease enlisted in table 4.

Table 4. Symptoms asked by the overseer doctor to pregnant woman with suspected structural heart disease

\begin{tabular}{l} 
Symptoms \\
\hline Dyspneu/breathlessness \\
Orthopneu \\
Decrease of abiltty or inability to do exercise/daily activities \\
Swelling feet/legs \\
Cyanotic in infancy \\
Palpitation \\
History of heart disease/heart surgery \\
Cold sweat \\
Cough or dyspneu, felt before pregnancy and increasing in quality after \\
pregnancy
\end{tabular}

The majority of structural heart disease in pregnancy patients stated that the anamnesis done by the PHC officer was not thorough as compared to the anamnesis done in the Soetomo hospital, particularly in asking previous medical history and family medical history. Some of them also said that the PHC officer have taken lightly of their complain of breathlessness.

One informant have complained of feeling out of breath, but the PHC officer assign to her told her that her complain is caused by her pregnancy. Other informant said that one doctor at the PHC where she done her ANC want to refer her to the hospital due to her breathlessness complain, but because BPJS procedural she should referred from another PHC where she enlisted as BJPS user. In the new PHC, the officer there said to rest at home first, because it is normal for a pregnant woman for feeling out of breath due to her pregnancy, and should the complain persists after resting, she should come back to the PHC.

\section{Physical examination}

The overseer doctors agree that thorough physical examination only done once at the first ANC visit unless there are new symptoms arise. Initial vital sign and obstetric examination done by midwife, the overseer doctors will only do general examination and will not repeat obstetrical examination, unless the midwife found abnormality, while vital signexamination only repeated if the patient looked ill.

In physical examination, just like in anamnesis procedure, there are differences between examination done in patient with suspicion of structural heart disease and the low risk patient. In the low risk patient, the overseer doctors stated that they will look at the conjunctiva for sign of anemia, enlargement of thyroid gland, swelling in inferior extremities and heart-pulmonary examination. While in pregnant patient with suspicion of structural heart disease, the overseer doctors will also look for cyanosis signs in lips and clubbing fingers, they will also listen more carefully for heart murmur.

\section{Counseling to pregnant patient with suspicion or proven structural heart disease}

Counseling to pregnant patient with suspicion or proven structural heart disease divided into counseling about the condition of the disease and counseling done to motivate the patient to approve the referral plan. All of the overseer doctors counsel the patient about how the cardiac disease will affect the pregnancy and both, mother's and fetus's, health. They also counsel the patient that the PHC unable to provide the service needed, so they will have to refer the patient with suspected or proven heart disease.

From the patients with structural heart disease in pregnancy we found that the PHC officers have explained the condition and why they were referred, but the explanation were felt inadequate, especially about when they should go to the referral hospital.

Table 5. Part of counseling that the patient felt unclear

\begin{tabular}{l} 
Part of counseling from the PHC doctor \\
\hline When the patient should go to the referral hospital, can the referral be \\
delayed? \\
Why pregnancy ca endanger structural heart disease patient? \\
\hline \\
Referral procedure and destination of suspected \\
or proven structural heart disease in pregnancy \\
patients
\end{tabular}

\section{Referral procedure}

A patient with structural heart disease in pregnancy stated that when the PHC where she done her ANC decided to refer her to confirm the suspicion of heart disease after she complained of breathlessness, the doctor in that PHC told her to return to the PHC where she registered as BPJS user, because referral could only be done by the PHC where she was registered.

To confirm the statement, we interviewed the BPJS Surabaya Branch representative officer. The representative officer said that from the first ANC, the PHC should confirm the status of the pregnant patient, whether they use BPJS or not and if they were registered as BPJS user. If the patient are not registered as BPJS user in that PHC, the patient can change their primary care provider to the $\mathrm{PHC}$ that they desire at the 
BPJS office. If the condition of the patient if unstable, BPJS allowed the referral to be done by all of the health provider which examined the patient, even if the patient was not registered there. In similar tone, the Surabaya Municipality Health Office representative also said that if the patient condition is unstable, the first PHC examined her should refer the patient straight to the hospital, instead of sending her off to another PHC. The decision of stability of the patient in question remained to be the doctor's privilege.

\section{Referral destination}

We give a simulated case of suspected structural heart disease in pregnancy with stable condition, and we asked the overseer doctor where they would refer the patient. The detail in table 8 .

From the data acquired from the patients structural heart disease in pregnancy, we found that there are patients who were first referred to other hospitals before being referred again to Dr Soetomo hospital because the first hospital can not provide the medical care needed (table 9).

Table 6. Referral destination of structural heart disease in pregnancy patient according the overseer doctor

\begin{tabular}{ll}
\hline \multicolumn{1}{c}{ Destination } & \multicolumn{1}{c}{ Reasoning } \\
\hline $\begin{array}{l}\text { Government hospital, } \\
\text { type C and B }\end{array}$ & $\begin{array}{l}\text { The coordination before and referral } \\
\text { process easier and government } \\
\text { hospital have better resource }\end{array}$ \\
$\begin{array}{l}\text { Government or private } \\
\text { hospital, type C or B } \\
\text { as long as they categorized in the } \\
\text { sama type } \\
\text { There are no formal guideline }\end{array}$ \\
$\begin{array}{l}\text { Destined department: } \\
\text { Cardiology }\end{array}$ \\
$\begin{array}{l}\text { The abnormality lie in cardiology } \\
\text { system } \\
\text { The obstetricianwill manage it better }\end{array}$ \\
Either are the same & There are no formal guideline \\
\hline
\end{tabular}

Table 7. Patient information of the referral process that they experience and the $\mathrm{PHC}$ reasoning

\begin{tabular}{ll}
\hline \multicolumn{1}{c}{ Referral pattern } & \multicolumn{1}{c}{ Reasoning } \\
\hline $\begin{array}{l}\text { Refer immediately } \\
\text { Told to get back to the PHC } \\
\text { where she was registered as BPJS } \\
\text { user }\end{array}$ & $\begin{array}{l}\text { The referral will not be } \\
\text { covered by BPJS if not } \\
\text { done according to the } \\
\text { procedure }\end{array}$ \\
\hline $\begin{array}{l}\text { Straight to type A hospital } \\
\text { To the type C or B hospital first }\end{array}$ & $\begin{array}{l}\text { Already a booked patient } \\
\text { at the type A hospital } \\
\text { Staged referral for BPJS } \\
\text { user }\end{array}$ \\
\hline
\end{tabular}

About the rules regarding referral process fo cases with suspected structural heart disease in pregnancy, the officer from Surabaya Municipality Health Office stated,

"In an Maternal and Perinatal Mortality and Morbidity Audit in Dr Soetomo hospital, one of the fetomaternal specialist advice that every case with suspected heart disease in pregnancy to be refer directly to Dr. Soetomo hospital's obstetric outpatient clinic or delivery room if the condition is unstable. Unfortunately, this statement have not been publicized."

The representative officer from BPJS said that,

"According Health Minister Regulation, referral should be done accordingly with the hospital type, so it should be done in stages, but this is not absolute. Referral can be done in accordance with the hospital's competency and the individualized cases. If a condition is considered to be unique, than the colegium involved should make standard operating procedure (SOP). This SOP will be discussed by the BPJS's Quality Control Team to make future direction regarding referral procedure."

\section{Other problems found in the PHC}

\section{$\mathrm{KI}$ access patients}

One of the overseer doctor thought that the patients who did not do her ANC at the PHC (she done ANC at midwife) and only came once to the PHC for laboratory examination might create problem.

"the patients who only came once to the PHC (access K1) to do laboratory result, and then continue their ANC at midwife, might produce problem. They might came early at first trimester, and the heart defect is so small, they did not have any sign or symptoms. And then when they continue the ANC at midwife, when they complain of breathlessness, the midwife is not competent to do auscultation and might delay the referral if she think the symptom caused by the pregnancy itself.." (the overseer doctor at $\mathrm{PHC}$ “D”)

Regarding K1 access patient, the officer from Municipality Health Office said that,

"the Municipality Health Office has prompted that every pregnant woman to do ANC at the 
PHC at least once, so they can receive integrated ANC. The whole point is to do risk screening and early intervention for pregnancy problems, because we realize that midwives are not fully competent to do physical examination and diagnosis of medical disease complicating pregnancy. But we have not regulate the time to do this ANC."

\section{Preconceptional counseling}

Female patients with congenital or rheumatic heart disease are quite often visit the PHC, but the GP at the PHC (represented by the overseer doctor) felt that the preconceptional and reproductive health counseling in this patients is not their competency. One of the patient stated that she thought her heart condition was resolved because she did not have any complain anymore and the doctor who diagnose her with heart defect when she was a child said nothing about pregnancy caution or her prognosis, so when the doctor at the PHC where she done her ANC asked her about if she have a cardiac disease, she said no. To answer our question, if the Surabaya Municipality Health Office have a program that can be use to provide preconceptional counseling, the representative officer stated,

"We have School health Program for elementary school, junior high school and high school students. In this program, we conduct health survey and provide medical check up for those students. We have a health book for each student, inside this book we can found information and medical history including the family medical history. We also place educational information about reproductive health in these books, but not anything specific to cardiac disease, not yet."

\section{The screening process of structural heart disease in pregnancy at the public health centre}

Schoon et. al. stated that improvement in detection of heart disease at the primary health facility is imperative in decreasing the morbidity and mortality of structural heart disease in pregnancy cases ${ }^{5}$. In rheumatic heart disease cases, there might be a history of asymptomatic pregnancy and the patient might appears normal. The condition is asymptomatic early in its natural history and is diagnosed when the majority of women are medically examined only during the first antenatal visit or when disease is of a severity that it produces symptoms ${ }^{5}$. To improve this detection level, the scree-ning for cardiac disease should be done routinely to every pregnancy so that the referral to the specialist centre can be done faster and earlier ${ }^{6}$.
Congenital heart disease in pregnancy cases is relatively seldom encountered by individual doctor, which lessen the experience of each doctor, and this in return is one of the causes the high mortality and morbidity of such cases in United States of America ${ }^{7}$. Lectures and review of pregnancy physiology and pathology including heart disease in pregnancy were last given in 2013. This meager experience and knowledge will reduce the detection level of structural heart disease in pregnancy at the primary health facility ${ }^{8}$.

This low knowledge could become obstacle for doctors to adhere to the guideline available, in this case, guideline of screening of structural heart disease in pregnancy. The reluctancy to adhere to a guideline also affected by feedback from the referral hospital ${ }^{9}$.

Consultation of new pregnant patient to the GP, which in several PHC only can be done to the overseer doctor, could make the screening process slower, because when the overseer doctor are not available, the consultation done by phone or the patient was sent home and told to come back when the overseer doctor present. The lack of competency of the midwife to do auscultation might cause the heart defect overlooked at the first visit, with risk of detorioration of the patient condition before the next visit. The delayed screening and pregnancy examination and the lack of knowledge of medical officer about the impact of pregnancy to cardiac disease patient are main source of morbidity and mortality ${ }^{5}$.

\section{Anamnesis}

The significancy of anamnesis in the screening of structural heart disease in pregnancy were shown in the study by Divanovic et. al, where all the patients with cardio-respiration disease were detected through anamnesis while the role of physical examination were lesser $^{10}$. To make the anamnesis more accurate, other symptoms and complain should also be asked, for instance, palpitation and feet swelling, which in Campanharo et. al study often accompanied the symptoms of breathlessness ${ }^{11}$. Watkins also reported, as mentioned by Schoon et. al. that the most often reported cardiac symptoms during pregnancy are breathlessness and paroxysmal nocturnal dyspnoea ${ }^{8}$

Inquiring details of symptoms such as how big of the disturbance to the daily activities can help to differ between physiologic and pathologic condition, for example, if the pregnant woman with breathlessness so severe that she can not perform the everyday activities or if the complain disturbed her sleep, it could mean that she at least have class III heart failure according to New York Heart Association (NYHA). Resting tachycardia, pathologic murmur and/or sign of heart failure signify 
the need of echocardiography evaluation as soon as possible ${ }^{12}$.

In anamnesis process, the history of rheumatic fever and history of cardiac disease at infantile and childhood periode should be asked, patient should be encourage to report every abnormalities even if it no longer give symptoms, because $92 \%$ patients in the Divanovic and Buchmann studies as mention by Watkins et. al., have been diagnosed with cardiac defect in infantile, childhood or some time before pregnancy. ${ }^{8}$. Other patients have history of cardiac defect surgery. ${ }^{13}$ Anamnesis regarding family medical history might give information about cardiac defect and other syndromes with cardiac structural anomaly, such as Marfan syndrome. ${ }^{14}$

\section{Physical examination and other} diagnostic modality

Changes in vital sign normal range during pregnancy provide obstacles in detecting cardiac anomaly. Based on this, Loerup et. al design a metaanalysis study to determined the range of normal vital sign during pregnancy, but unfortunately the study is not finished yet. ${ }^{15}$ Another source of normal vital sign range at term pregnancy, Dennis and Hardy studied 258 woman in term pregnancy who underwent cesarean section, they found the normal range of vital sign to be pulse $64-$ $104 \mathrm{bpm}$, respiration rate 15-21 bpm and SpO2 97\% $100 \% .^{16}$

According to the overseer doctors, the abnormalities from physical finding that support the suspicion of cardiac disease are heart murmur, cyanosis and clubbing finger. Cyanosis sign which is also a sign of hypoxemia can be seen in face, tingue mucosal membrane and fingers, while clubbing finger which is a sign of chronic hypoxemia, can be found in the hand. ${ }^{17}$

Heart murmur is the most physical abnormality mentioned by the overseer doctors in cases of suspected cardiac defect in pregnancy. But according to the study of Divanovic et. al., auscultation is not sensitive enough to detect cardiac abnormality since it is dependent to the competency of the examiner and other factors. ${ }^{10}$ ECG test in structural heart disease screening have been described in some studies, but the accuracy in diagnosing structural heart disease is not adequate. 18,19,20,21,22,23 Nqayana et. al. stated that clinical examination is not sufficient to diagnose structural heart disease in pregnancy, to confirm the diagnosis, echocardiography is still needed. ${ }^{24}$

\section{Counseling to pregnant patient with suspected or proven structural heart disease}

When counseling the pregnant patien with suspected structural heart disease, the GP at PHC should emphasis that the diagnosis of structural heart disease must be confirmed by echocardiography, available only at certain hospitals, that the diagnosis needed to be confirmed as soon as possible to prevent complications to mother and fetus, so that the patient and her family more motivated to come to the referral hospital. Schoon et. al. pointed that in most cases, the ignorance regarding pregnancy complication related to the heart condition and the available therapy appears to be prominent. ${ }^{5}$ Doctors should always aware that even if the condition seem to be stabil and under control before pregnancy, the physiologic changes in pregnancy will give extra load to the heart. This present hazard for the abnormal cardiac. Improvement of primary health facility quality in screening of cardiac structural defect and good counseling training for GP are priorities for solving this problems. $^{5}$

\section{Referral procedure and destination of suspected or proven structural heart disease in pregnancy patients}

\section{Referral procedure}

In this study, one structural heart disease in pregnancy patient said that she was told to go to the PHC where she was enlisted as BPJS user, when the PHC where she did her ANC suspected her with heart abnormality, and this make her referral process delayed for some days. Referral delay is one of the factors contributing to mortality in Soma-Pillay et. al. study. The researcher said that mortality contributing factors that preventable are the delay of seeking help ( $>50 \%$ patients), the lack of knowledge and skill of the medical officer $(30 \%)$, referral delay and inappropriate therapy. ${ }^{6}$

\section{Referral destination}

Until now, there still no referral scheme for pregnancy with with suspected or proven cardiac disease from the PHC to hospital in Indonesia. In our study, we found two patients were referred to another hospitals before they were referred again to the Dr. Soetomo hospital. This might delay the management, cost ineffiency and the patient feel uncomfortable.

There are few referral scheme for pregnancy complicated with structural heart disease that can be use, for example the guideline from King Edward Memorial Hospital (KEMH). KEMH guideline stated that risk evaluation in pregnanct woman with heart murmur or history of cardiac defect should be done as early as possible in a joint clinic of obstetric, cardiology and anesthesia specialist. Pregnant woman suspected or 
proven with structural heart defect referred directly to the tertiary hospital to underwent risk evaluation and pregnancy management as early as possible and the referral note should be directed to obstetric specialist who familiar with pregnancy complicated by structural heart disease cases. ${ }^{25}$

Pregnant woman with "low risk" congenital heart defect will also gain benefit from early referral to the tertiary centre. After risk evaluation,"low risk" woman may continue her ANC and delivered at local hospital, while intermediate and high risk patients should continue their ANC and delivered at referral hospital qualified for pregnancy with structural heart disease management. ${ }^{26}$

In the Nqayana et. al. study, echocardiography change the first diagnosis in 7 patients, this reflexes the importance of early referral to the specialist centre in pregnancy with structural heart disease cases. ${ }^{22}$ Soma-Pillay et.al reviewed on near-miss cases and found that delay of ANC, pregnant woman who did not do ANC routinely and the lack of awareness are causes of morbidity. ${ }^{6,22}$ The next problem as mentioned by SomaPillay et. al is the non-existent referral guideline of pregnancy with structural heart disease cases and where should the joint team needed for risk evaluation being assembled, in the secondary referral hospital or the tertiary. ${ }^{6}$ We propose a guideline scheme for referring cases of pregnancy with suspected or proven structural heart disease (attachment 1).

\section{Other problems found in the PHC}

\section{$\mathrm{KI}$ access patients}

The midwives curriculum in Indonesia does not include auscultation as one of the competency every midwife should mastered. As a consequence, the midwife in Indonesia unable to perform general physical examination needed to pregnancy risk screening, therefore every pregnant woman should visit GP at least once during her pregnancy to do risk screening. This visit can be done in PHC or any other primary health facility. If a woman found to be low risk, she can continue to do her $\mathrm{ANC}$ at the PHC,a but when she was found to be high risk she will be referred early. Non booked patients almost always came at the last trimester with complication, this was observed in Matlala et. al. study in pregnant women with heart disease in Africa, this study was mention by Watkins et. al. ${ }^{8}$ Only of Soma-Pillay et. al. subject who have access to specialist care during their pregnancy. ${ }^{6}$

\section{Preconceptional counseling}

PHC is one of the means that can be utilized for screening structural heart disease in pregnancy to reduce the mortality and morbidity, especially in Indonesia. Another roles for PHC is surveillance of structural heart disease female patient in its territory, pregnant or not pregnant.

Ideally, the counseling process of heart disease and its effect on reproductive health should be done by the doctor who diagnosed it, in congenital heart disease, this means the cardiologist or the pediatrician. Of 8 patients we have interviewed, 7 have congenital heart disease, 5 of them already diagnosed at childhood. Only one from those 5 who understand her risk of getting pregnant. Four of those 5 did not understand nor received any information about their heart condition, whether its progressive or not, improving or not, or its effects on their reproductive health. These four patients already stopped seing their cardiologist because they no longer have any complain.

Brickner found in his study that there are a lot of congenital heart disease patients who were not followed until adulthood, these patients or the doctor who manage them felt their disease have resolved. ${ }^{13}$ According to Dearani et. al, there are 3 reasons for this, the patient are no longer longer do routine check up to the specialist who manage her, the doctor who diagnosed her did not educate the patient or her family about the disease natural history and how to maintain the patient optimal condition, and third, the doctor who manages her after adulthood and experience of the complexity of congenital heart disease cases at adulthood. ${ }^{7}$

Silversides et. al found that there were many cardiologists who did not counsel their female patients about pregnancy and the risks of pregnancy in relation to their heart condition, in the study, 18 patients $(16 \%)$ heart condition were contraindicated for pregnancy, but only 9 were told not to get pregnant. ${ }^{27}$ In the same study, it was found that many of these women do not have good understanding about contraception and pregnancy effect on congenital heart disease ${ }^{27}$ Since adolescence, female congenital heart disease patient should receive counseling about contraception and the effect of pregnancy on congenital heart disease. ${ }^{27}$

All women who have valvular heart disease should received preconceptional counseling that include risk prediction and contraception choices, this counseling should be done by joint team of cardiologist and obstetric specialist and other specialist if needed. ${ }^{28}$ Zühlke et. al. as mentioned by Soma-Pillay et. al, reported in the REMEDY study that from 1825 reproductive age women who have rheumatic heart disease, only 3,6\% used contraception. ${ }^{29}$ A publication by Sliwa et. al. 
emphasized the need of counseling about the maternal and fetal risk to every woman who suffer from valvular heart disease and should contain information of complications such as heart failure and valve thrombosis. That can occur during and after delivery. ${ }^{29}$

Centre for Maternal and Child Enquiries (CEMACH) just as mentioned by Nanda et.al, suggest that all congenital heart disease patient given proper preconceptional counseling to prevent an unwanted pregnancy in teenager and to ensure that the patients who have risk of obstetric of cardiac complications realize their risk and when they are pregnant have good management plan. ${ }^{30}$

In Indonesia health system with the introduction of BPJS, structural heart disease patients eventually will visit PHC to obtain referral letter to the cardiologist, this visit provide opportunity to give them counseling about the patient condition, that at least would give those patients some information to discuss with their cardiologist.

The School Health Program, provided by the Municipality Health Office, also provide means to give early screening and counseling of structural heart disease to elementary, junior high and high school students. The screening process and the information of congenital and valvular heart disease should be incorporated in the Health Book and at times of school visit, PHC can provide counseling of the structural heart disease and it relation to reproductive health.

\section{CONCLUSIONS}

The screening process for structural heart disease in pregnancy is not done routinely and optimally at PHC, this may be caused by the lack of knowledge and awareness of the general practitioner doctor. Counseling of pregnant woman with suspected or proven structural heart disease is done in the PHC to ensure the patient understand the diagnosis cannot be confirmed at the PHC hence the referal to the hospital. But the counseling about the need to confirm the diagnosis as soon as possible to prevent the confirmation still not done effectively, as there are some patient who did not understand this. Preconceptional counseling is still not done in the PHC because the lack of knowledge of the GP about the importance of preconceptional counseling inthese patients and because they are not sure who should do this counseling. There is still no formal guideline about the referral scheme of pregnancy with structural heart disease cases, and this make the overseer doctor do the referral of these cases just as other cases, whereas not every hospital can confirm the diagnosis as soon as possible or manage these cases.

\section{Suggestions}

The screening of structural heart disease must be done routinely in PHC, through anamnesis and physical examination. The points needed for screening can be added in the anamnesis and physical examination In the Maternal sheet to help the doctors incharge to remember what need to be asked and seek. To improve the knowledge and awareness of the GP and especially the overseer doctor, lectures of structural heart disease and its effect on pregnancy should be given, along with how to detect it in primary service. To optimize the screening process, we advice to add the minimum visit to the GP for every pregnant woman to two times min-imum during the pregnancy, once in the first trimester and once in the second trimester.

The overseer doctor and other GP in the PHC should give brief counsel the pregnant woman suspected or proven with structural heart disease so that the patient understand what need to be done and also brief preconceptional counseling to the woman with struc-tural heart disease who is not pregnant yet or to female teenager. Training how to do this counseling should be given to the GP and the overseer doctor. School Health program can be used as another means to do pre-conceptional counseling, information of the structu-ral heart disease and its relation to reproductive health can be inserted to the Health Book or leaflet. Formal guideline of referral scheme for suspected o proven structural heart disease in pregnancy must be made as soon as possible and discussed with the BPJS and Municipality Health Office.

\section{REFERENCES}

1. Sihotang $\mathbf{J}$ and Gumilar KE. Persalinan dengan penyakit jantung kongenital RSUD Dr. Soetomo 2014-2016. Surabaya; 2016.

2. Arfianda D and Gumilar KE. Persalinan dengan penyakit jantung rheumatik RSUD Dr. Soetomo 2014-2016. Surabaya; 2016

3. Trihastuti $\mathrm{N}$ and Gumilar KE. Luaran maternal dan neonatal kehamilan dengan penyakit jantung rheumatik RSUD Dr. Soetomo. Surabaya; 2016.

4. Baumgartner TA, Strong CH, Hensley LD. Conducting and reading research in health and human performance. New York: McGraw-Hill; 2002.

5. Schoon M, Bam R, Wolmarans L. Cardiac disease during pregnancy - a free state perspective on maternal morbidity and moratlity. Cardiovascular Journal of Southern Africa. 1997.

6. Soma-Pillay P, Seabe J, Sliwa K. The importance of cardiovascular pathology contributing to maternal death: Confidential enquiry into maternal deaths 
in South Africa, 2011-2013. Cardiovascular Journal of Africa. 2016.

7. Dearani J, Connoly H, Martinez R et al. Caring for adults with congenital cardiac disease: success and challenges for 2007 and beyond. Cardiology in the Young. 2007.

8. Watkins D, Sebitloane M, Engel M, Mayosi B. The burden of antenatal heart disease in South Africa: a systematic review. BMC Cardiovascular Disease. 2012.

9. Ward MM, Vaughn TE, Uden-Hollman T, et al. Physician knowledge, attitudes and practices regarding a widely implemented guideline. Journal of Evaluation of Clinical Practice. 2002.

10. Divanovic E and Buchmann, E. Routine heart and lung auscultation in prenatal care. International Journal of Gynecology \& Obstetrics. 1999:247-251.

11. Campanharo F, Cecatt J, Haddad S, et al. The impact of cardiac diseases during pregnancy on severe maternal morbidity and mortality in Brazil. PLos ONE. 2015.

12. Elliot C, Sliwa K, Burton R. Pregnancy and cardiac disease. The South African Medical Journal. 2014.

13. Brickner M. Cardiovascular management in pregnancy: Congenital heart disease. Circulation. 2014

14. Lin A, Basson C, Goldmutz E, et al. Adults with genetic syndromes and cardiovascular abnormalities: clinical history and management. Genetic Medicine. 2008.

15. Loerup L, Pullon R, Fleming S, et al. Trends of vital sign with gestational age in normal pregnancies: a systematic revie protocol. BMJ Open. 2016.

16. Dennis A and Hardy L. Defining a reference range for vital signs in healthy term pregnant women undergoing cesarean section. Anesthesia and Intensive Care. 2016.

17. McMullen S and Patrick W. Cyanosis. The American Journal of Medicine. 2013.
18. Ahamed M, Ahmad Z, Abhilash T. Approach to infants and children with cyanotic heart disease. Kerala Heart Journal. 2015;30-35.

19. Ayyachamy ST, Yip J, Poh K. ECGs of Structural heart disease: Part 2. Singapore Medicine Journal. 2012;77.

20. Brink A and Neill C. The electrocardiogram in congenital heart disease: with a special reference to left axis deviation. Circulation. 1955.

21. Oglesby P, Gordon S, Campbell J. The electrocardiogram in congenital heart disease: a preliminary report. Circulation. 1951.

22. Hendryx E. Identifying ECG clusters in congenital heart disease. Texas: Rice University. 2015.

23. Khairy $\mathrm{P}$ and Marelli A. Clinical use of ECG in adults with congenital heart disease. Circulation. 2007.

24. Nqayana T, Moodley J, Naidoo D. Cardiac disease in pregnancy. Cardiovascular Journal of Africa. 2008.

25. KEMH. Clinical practice guideline: Cardiac disease. Government of Western Australia: Morth Metropolitan Health Service Women and Newborn Health Service. 2016.

26. D'Souza R, Sermer M, Silversides C. Pregnancy in women with congenital heart disease. Obstetric Medicine. 2015.

27. Silversides C, Kovacs A, Harrisons J, et al. Pregnancy and contraception in congenital heart disease: what women are not told. Journal of the American College of Cardiology. 2008.

28. Sliwa K, Johnson M, Zilla P, Roos-Hesselink J. Management of valvular disease in pregnan-cy: a global perspective. European Heart Journal. 2015.

29. Sliwa $K$ and Anthony J. Risk assesment for pregnancy with cardiac disease - a global perspective. European Journal of Heart failure. 2016.

30. Nanda S, Melson-Piercy C, MacKillop L. Cardiac disease in pregnancy. Clinical Medicine. 2012. 